\title{
Two-stage collision: Exploring the birth of Pangea in the Variscan terranes
}

\author{
Ricardo Arenas ${ }^{\mathrm{a} *} *$, Rubén Díez Fernández ${ }^{\mathrm{a}, \mathrm{b}}$, Sonia Sánchez Martínez ${ }^{\mathrm{a}}$, Axel Gerdes ${ }^{\mathrm{c}, \mathrm{d}}$, \\ Javier Fernández-Suárez ${ }^{\text {a }}$, Richard Albert ${ }^{\text {a }}$ \\ a Departamento de Petrología y Geoquímica and Instituto de Geociencias (UCM, CSIC), Universidad Complutense de Madrid, 28040 Madrid, Spain \\ ${ }^{\mathrm{b}}$ IDL, Departamento de Geociências, ECT, Universidade de Évora, Apartado 94, 7001-554 Évora, Portugal \\ ${ }^{\mathrm{c}}$ Institut für Geowissenschaften, Mineralogie, J.W. Goethe Universität, Frankfurt am Main, Germany \\ ${ }^{\mathrm{d}}$ Department of Earth Sciences, Stellenbosch University, Private Bag X1,Matieland 7602, South Africa
}

\section{a b s t r a c t}

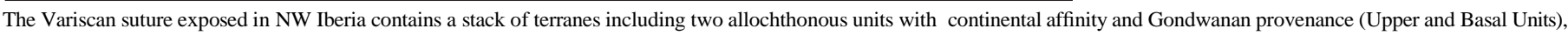

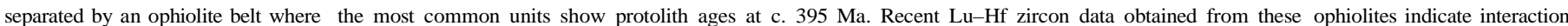

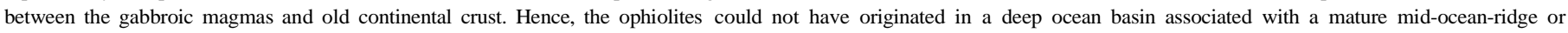

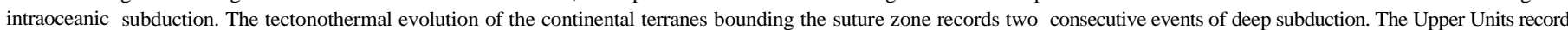

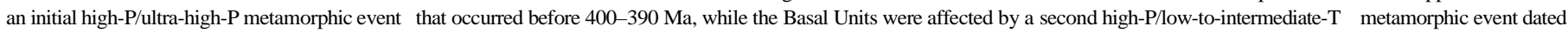

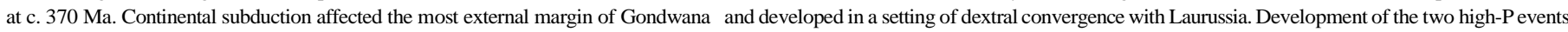

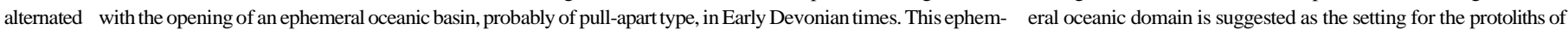

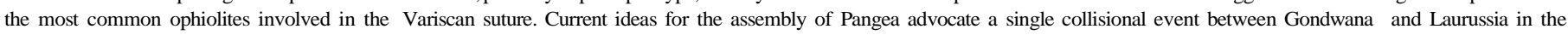

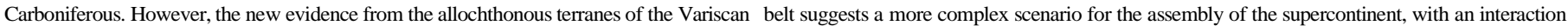

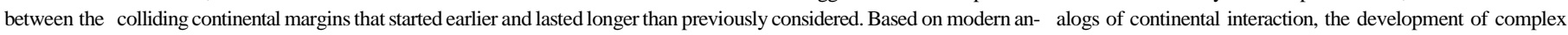
collisions, as here suggested for Gondwana and Laurussia during the assembly of Pangea, could have been the norm rather than the exception throughout Earth history.

Keywords: Assembly of Pangea, Allochthonous,Variscan terranes, NWIberian Massif

\section{Introduction}

It is broadly accepted that the assembly of Pangea occurred in Carboniferous and Early Permian times, after a long stage of continental convergence that ended with the closure of the Rheic Ocean (e.g. Nance et al., 2010 and references therein) and the collision of Gondwana and Laurussia (Stampfli and Borel, 2002; Murphy and Nance, 2008). This collision resulted in the formation of the Variscan-Appalachian- Alleghanian orogen, which extends from Europe to eastern North America and contains key information for reconstructing the amalgam- ation history of the supercontinent. In the Variscan belt, the oldest tectonothermal events are preserved in a complex suture zone that can be traced from the Iberian Peninsula to the Bohemian Massif (Fig. 1).

\footnotetext{
* Correspondingauthor.Tel.:+34639601919,+34915442535.

E-mail addresses: arenas@geo.ucm.es (R. Arenas), georuben@usal.es (R. Díez Fernández), s.sanchez@geo.ucm.es (S. Sánchez Martínez), gerdes@em.uni-frankfurt.de (A. Gerdes),jfsuarez@geo.ucm.es (J. Fernández-Suárez), r.albert@geo.ucm.es (R. Albert).
}

This belt is affected by several oroclinal folds, but the original geometry was broadly linear (Matte, 2001; Martínez Catalán, 2011; Weil et al., 2012). The suture zone is made up of a stack of allochthonous terranes with ophiolites and high-P (HP) and ultra-high-P (UHP) metamorphic rocks. One of the most distinctive features of the Variscan belt is the presence of two different events of HP metamorphism that appear to have occurred relatively close in time, but were separated by the develop- ment of oceanic basins. This evolution is unusual in large collisional belts, whose tectonothermal evolution is commonly interpreted as reflecting a single HP or UHP metamorphic event associated with subduction of one of the colliding continental margins (Platt, 1986; Beaumont et al., 2009). In the Variscan belt, both HP events and the development of some of the oceanic domains occurred after the earliest Devonian and are thus broadly coeval with the initial stages of the assembly of Pangea. This paper presents a short summary of the origin and tectonothermal evolution of the allochthonous terranes involved in the Variscan suture, and proposes a conceptual model to integrate part of this history in the context of Pangea formation. The geological section exposed in the NW Iberian Massif is taken as an example and described in some detail, but 


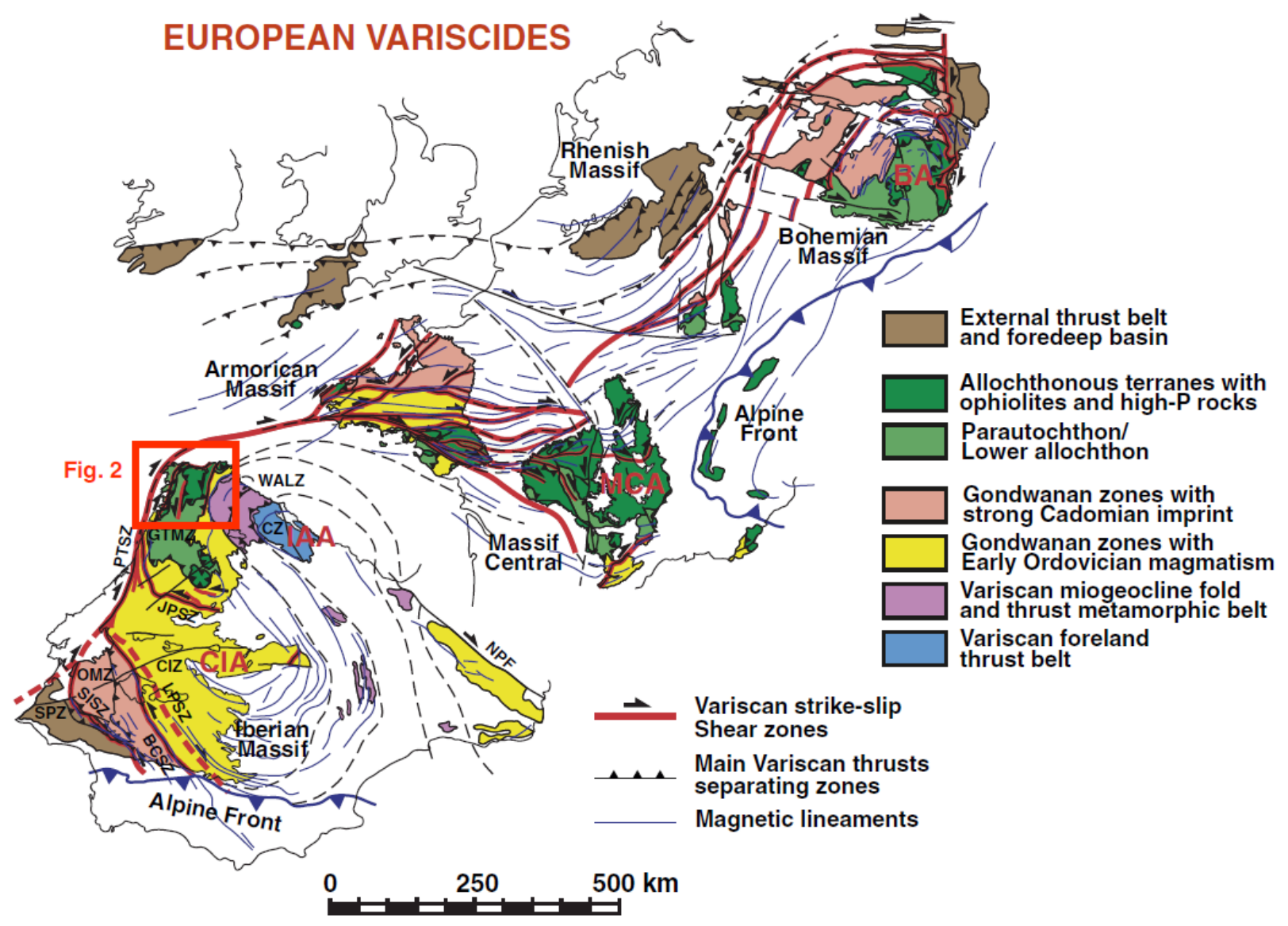

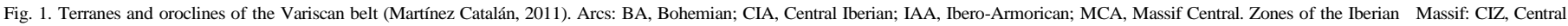

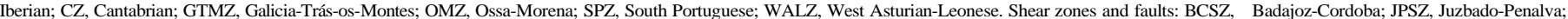
LPSZ, Los Pedroches; NPF, North Pyrenean; PTSZ, Porto-Tomar; SISZ, Southern Iberian. Location of the geological map and section presented in Fig. 2 are also shown.

allochthonous terranes are fairly continuous along the suture and largely comparable throughout the European Variscan belt (Faryad and Kachlík, 2013; Kroner and Romer, 2013). Recent isotopic and geochronologic data on the origin of the Ophiolitic Units and U-Pb geochronological constraints on the HP events provide new insights into the early events involved in the formation of Pangea. The history of convergence and collision is probably longer and more complex than previously described.

\section{Terranes involved in the Variscan suture}

The NW Iberian section of the Variscan belt contains different ter- ranes with contrasting origins and tectonothermal evolution (Arenas et al., 1986; Martínez Catalán et al., 2009). The Central Iberian Zone represents the lowest sequence and together with a parautochthonous domain (or Schistose Domain) defines the main section of the Gondwanan margin involved in the Variscan orogen (Martínez Catalán et al., 2009) (Figs. 1 and 2). On top, a set of allochthonous terranes of al- leged exotic nature forms a nappe stack representative of the suture zone (Figs. 1 and 2). Three main groups of terranes have been identified, two of which show continental crustal affinities (Basal and Upper Units). These are separated by ophiolites representing the suture itself (Ophiolitic Units, Fig. 2).

Located immediately below the suture, the Basal Units contain metasedimentary rocks (comprising a thick pile of metagreywackes with minor metapelites, graphitic schist, calc-silicate lenses, metacherts and quartzites), calc-alkaline to alkaline-peralkaline metagranitoids, and some mafic rocks. Maximum depositional ages for the metasedimentary series range between Ediacaran and Early Ordovician (Díez Fernández et al., 2010, 2013), with Nd model ages between 1.78 and 2.22 Ga (Fuenlabrada et al., 2012). Major and trace element geo- chemistry of the metagreywackes suggest deposition in association with a periGondwanan arc system built upon a thinned continental margin. The calcalkaline (c. 493 Ma; Abati et al., 2010) and alkaline- peralkaline (c. 475-470 Ma; Díez Fernández et al., 2012a) granitoids were generated within this arc, suggesting an evolution from conver- gence to continental rifting. The Basal Units are considered to represent a section of the most external margin of Gondwana located somewhere between the West African and Saharan cratons (Díez Fernández et al., 2010). The first tectonothermal event recorded in these units is a HP and low- to intermediate-T (LIT) event dated at c. 370 Ma (Rodríguez et al., 2003; Abati et al., 2010). A variety of HP mica schists and orthogneisses, C-type eclogites and some blueschists were formed at this time (Arenas et al., 1995, 1997; Rodríguez et al., 2003; López Carmona et al., 2013).

Resting on top of the suture zone, the Upper Units consist of a pile, 10-12 $\mathrm{km}$ thick, of metasedimentary rocks (mainly metagreywackes), large massifs of calc-alkaline orthogneisses, and gabbros with composi- tions of island-arc tholeiites, together with medium to high grade mafic rocks, including B-type eclogites (Coleman et al., 1965) and HP granu- lites, and some ultramafic massifs. The low grade metagreywackes lo- cated in the uppermost position have a Middle Cambrian maximum depositional age (Fernández-Suárez et al., 2003), with Nd model ages ranging between 0.72 and $1.22 \mathrm{Ga}$, and major and trace element compositions typical of active margin settings (Fuenlabrada et al., 2010). Protolith ages for gabbros and granitoids range between 490 and 520 Ma (Fernández-Suárez et al., 2007; Andonaegui et al., 2012). These units were part of a Cambrian peri-Gondwanan magmatic arc, and were located west of the external margin section represented by 


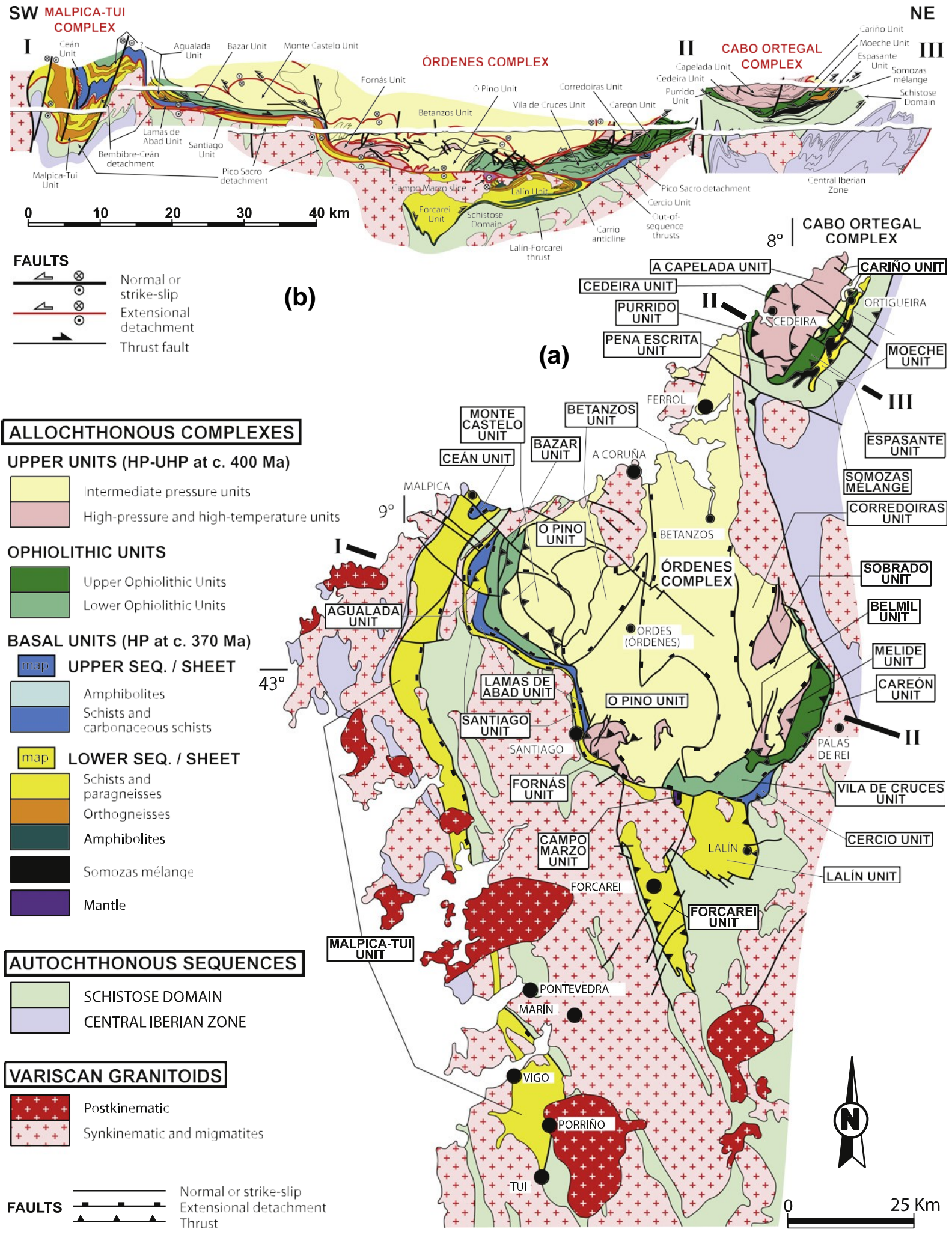

Fig. 2. (a) Geological map of the allochthonous complexes of the NW Iberian Massif (Galicia region), and (b) composite cross section, showing the distribution and general structure of the terranes involved in the Variscan suture. The location and name of the most representative units are indicated.

the Basal Units (Díez Fernández et al., 2010; Fuenlabrada et al., 2010). The Upper Units may be divided into two groups according to metamor- phic criteria: an uppermost section with intermediate-P metamorphism ranging from the chlorite zone to the granulite facies, and a lower section showing HP and high- $\mathrm{T}$ (HT) metamorphism dated at c. 400- 390 Ma (Ordóñez Casado et al., 2001; Fernández-Suárez et al., 2007).
The latter metamorphic event reached UHP conditions in other domains of the Variscan belt (Lardeaux et al., 2001). The main tectonothermal events recorded in the uppermost section are Cambrian in age and were probably developed in response to the accretionary dynamics of the peri-Gondwanan arc system (Abati et al., 1999, 2007; Díaz García et al., 2010). 
The ophiolites of NW Iberia have received considerable attention in the past few years with papers describing in detail their lithologies, chem- ical compositions and isotopic geochronology. It is now well-established that their igneous protoliths range quite widely in age, thereby precluding their generation within a single oceanic domain. Two groups of Ophiolitic Units have been distinguished (Fig. 2): an older group (Lower Ophiolitic Units) containing metaigneous rocks of Late Cambrian age (c. 497- $495 \mathrm{Ma}$ ), and a younger group (Upper Ophiolitic Units) including gabbro- ic rocks of Devonian age (Emsian-Eifelian; c. $395 \mathrm{Ma}$ ).

The Cambrian ophiolites comprise either thick sequences of greenschists (with island-arc tholeiite compositions), with some alter- nations of phyllites and rare tonalitic orthogneisses (Vila de Cruces Ophiolite; Arenas et al., 2007a; Fig. 2), or c. $4000 \mathrm{~m}$ of HT metagabbroic amphibolites with N-MORB affinities and minor ultramafic rocks (Bazar Ophiolite; Sánchez Martínez et al., 2012; Fig. 2). The protoliths of the Vila de Cruces Ophiolite were formed during the opening of a back-arc basin at the periphery of Gondwana. In contrast, based on its chemical composition and structural position, the Bazar Ophiolite probably rep- resents a relic of the Cambrian peri-Gondwanan Iapetus-Tornquist Ocean, accreted below a system of peri-Gondwanan volcanic arcs. This accretion is dated at c. $475 \mathrm{Ma}$ based on U-Pb zircon geochronology for the timing of the HT metamorphism affecting the mafic protoliths. The Lower Ophiolitic Units are interpreted to represent a series of mafic complexes linked to the dynamics affecting the most external margin of Gondwana in Cambrian-Early Ordoviciantimes.

The Middle Devonian ophiolites are the most abundant group found in the Variscan suture (Murphy et al., 2011). In addition to NW Iberia, they occur in the Lizard Complex (Lizard Ophiolite; Clark et al., 1998; Nutman et al., 2001), in the Armorican Massif (Drain Ophiolite; Ballèvre et al., 2009, 2012), and in the Bohemian Massif (Ślęża Ophiolite; Dubińska et al., 2004; Kryza and Pin, 2010). In Galicia (NW Spain), the Careón Ophiolite (395 \pm 2 Ma, U-Pb zircon in metagabbro; Díaz García et al., 1999; Pin et al., 2002; Fig. 2) has received special attention and can be considered the type example of the group. It is made up of three imbricate slices, the thickest (c. $1000 \mathrm{~m}$ ) of which con- tains a sequence of peridotites overlain by $500 \mathrm{~m}$ of isotropic gabbros. Both the peridotites and the gabbros are intruded by stocks of pegmatit- ic gabbros and numerous doleritic dykes. The ophiolite contains no sheeted dyke complex and no volcanic or sedimentary rocks, at variance with common N-MORB oceanic lithosphere generated at a mid-ocean ridge. The mafic rocks have compositions typical of island-arc tholeiites (Sánchez Martínez et al., 2007). The U-Pb zircon age obtained for this ophiolite is relatively close to the time calculated for its accretion (c. $377 \mathrm{Ma},{ }^{40} \mathrm{Ar}{ }^{39} \mathrm{Ar}$ on hornblende concentrate; Dallmeyer et al., 1997), therefore the unit represents a section of buoyant oceanic lithosphere that escaped subduction beneath Laurussia. New U-Pb zircon data obtained from other upper ophiolites in NW Iberia yielded similar crystallization ages for the mafic protoliths (395 \pm 3 Ma for the Purrido Unit: Sánchez Martínez et al., 2011; $400 \pm 3$ Ma for the Moeche Unit: Arenas et al., in press; Fig. 2). Moreover, a combined isotopic ( $\mathrm{Lu}-\mathrm{Hf}$ in zircon and $\mathrm{Sm}-\mathrm{Nd}$ in whole rock) study of these ophiolites shows that a suite of Devonian gabbros with juvenile isotopic compositions and mantle provenance (the mafic protoliths of the ophiolites) interacted with old continental crust and were affected by limited mixing (Sánchez Martínez et al., 2011; Arenas et al., in press). The involvement of a continental component is revealed by Paleoproterozoic Hf model ages in some of the zircons, which is inconsistent with the generation of the igneous protoliths in an intra-oceanic setting far removed from continents.

\section{A two-stage collision model for the early history of Pangea}

The Upper Units have been previously interpreted as a section of a periGondwanan volcanic arc that rifted off the continental margin in CambrianEarly Ordovician times and drifted northward, opening the Rheic Ocean in its wake. This rifting would have coincided with the rift and drift of the Avalonian microcontinent. The Upper Units, howev- er, would have had a different identity and provenance since they were located further to the east along the paleo-margin of Gondwana (Abati et al., 2007; Gómez Barreiro et al., 2007; Díez Fernández et al., 2010). The HP or UHP metamorphic event that affected the lower section of the Upper Units at c. 400-390 Ma would have been generated during the accretion of this terrane to the southern margin of Laurussia, this process highlighting the switch from a divergent to a convergent setting in the evolution of the Rheic Ocean. The geodynamic evolution hitherto suggested for the Upper Units implies that the ophiolites involved in the Variscan suture were developed in the realm of the Rheic Ocean. The Cambrian ophiolites - with the exception of the Bazar Ophiolite - would be related to early stages in the opening of this ocean, while the Devonian ophiolites would have been formed during the final stages of its closure (Arenas et al., 2007b). For this reason, it has been proposed that the Devonian ophiolites were formed in a northward dipping intra- Rheic Ocean supra-subduction zone located close to the southern margin of Laurussia (Díaz García et al., 1999; Sánchez Martínez et al., 2007). Such intraoceanic subduction zone would have generated buoyant oceanic lithosphere that would have readily accreted beneath Laurussia and eventually been obducted over the external margin of Gondwana (Basal Units) at the beginning of the Variscan deformation (c. $370 \mathrm{Ma}$ ). Furthermore, the activity of this intraoceanic subduction zone would have consumed a significant tract of the Rheic Ocean, thus explaining the general absence of typical N-MORB lithosphere in the Variscan suture.

However, the aforementioned models that link the generation of the Devonian ophiolites to an open-ocean setting are inconsistent with the new isotopic data that clearly show the interaction of the gabbroic protoliths with old continental crust. Many of the zircons analyzed in mafic rocks from the Purrido and Moeche ophiolites show Lu-Hf isotopic compositions only compatible with a continental origin. These zircons can be only interpreted as inherited crystals incorporated into the mafic magmas (Sánchez Martínez et al., 2011; Arenas et al., in press). Consequently, there is no conclusive evidence to link the gener- ation of the Devonian ophiolites either to the evolution of the Rheic Ocean or to an intraoceanic subduction zone active in a mature ocean basin. If the connection between the Variscan suture of NW Iberia and the evolution of the Rheic Ocean is called into question, so must the interpretation of the Upper Units as a peri-Gondwanan terrane that drifted away during the opening of this Paleozoic ocean. Moreover, problems also exist in attributing the development of HP-UHP meta- morphism in the trailing edge of a rather small terrane to its collision with Laurussia. The tectonothermal evolution expected for the accretion of a small, ribbon terrane to a large continent would be one more com- patible with soft collision, without generation of important subduction and, hence, lacking HP-UHP metamorphism. In contrast, the latter is usually associated with deep subduction of the thinned margin of a large continent during its collision with another large continent (Warren et al., 2008; Beaumont et al., 2009).

It is also noteworthy that the age of the HP-UHP metamorphic event in the Upper Units, which is constrained to be no younger than 400- $390 \mathrm{Ma}$ (U-Pb zircon; Ordóñez Casado et al., 2001; Fernández-Suárez et al., 2007), is similar to that of the mafic rocks of the Upper Ophiolitic Units, repeatedly dated at c. 400395 Ma (U-Pb zircon; Díaz García et al., 1999; Pin et al., 2002, 2006; Sánchez Martínez et al., 2011; Arenas et al., in press). In the case of the HP metamorphic event, the U-Pb geochronology provides the age of the HT zircon growth, which occurred sometime after the continental margin became involved in the subduction system. Accordingly, the peak pressure of the HP event must have been reached prior to 400-390 Ma since this age likely marks a point along the exhumation/decompression path (Fernández- Suárez et al., 2007). This subduction must also predate the generation of the Devonian mafic rocks, as expressed in recent papers focused on the origin of the allochthonous terranes of NW Iberia (Sánchez Martínez et al., 2007; Martínez Catalán etal., 2009). 
Hence, the new data from the allochthonous terranes of NW Iberia, in particular Lu-Hf isotope geochemistry of the Devonian ophiolites and detailed U-Pb geochronology of the two HP metamorphic events, seem to be more consistent with the development of two successive collision events between Gondwana and Laurussia, each taking place in a context of oblique convergence and separated in time by the opening of a rather wide oceanic basin, probably of pull-apart type.

The allochthonous Upper Units are herein interpreted as the most external part of the Gondwanan margin, a rather wide continental shelf containing thick turbidite series intruded by large massifs of gabbros and granitoids. This lithological succession was formed during the activity of a volcanic arc in Cambrian times, having developed after an important episode of crustal extension and thinning. This conti- nental shelf did not witness significant new igneous activity or deforma- tion until the onset of the HP-UHP metamorphic event, and hence shows the characteristics of a typical passive margin for most of the Ordovician and Silurian. In the geological record covering this time interval there is no evidence suggesting any significant separation of this continental shelf from the Gondwanan mainland. Convergence be- tween Gondwana and Laurussia led to a first continental collision before 400-390 Ma, including the dextral subduction (Ábalos et al., 2003) of the most external and thinned part of the Gondwanan margin to the north accompanied by the first HP-UHP metamorphism. The southern margin of Laurussia acted as the upper plate in the subduction complex and the most important collision probably affected the eastern part of Avalonia and the Baltic margin (Fig. 3).

Renewed dextral motion between Gondwana and Laurussia favored the rapid generation of a rather wide pull-apart basin in Early Devonian times, which we interpret as the tectonic setting for the generation of the c. 395 Ma mafic rocks forming the most typical ophiolites involved
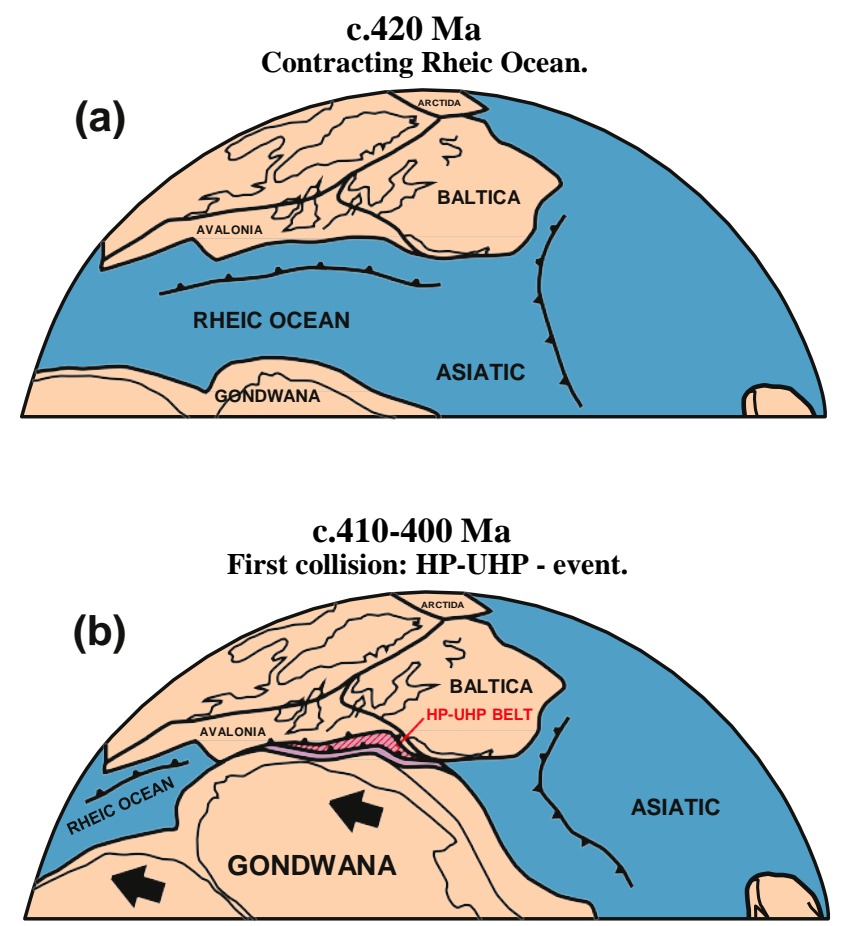

\section{UPPER UNITS}

Fig. 3. Reconstructions of (a) the Rheic Ocean realm at the Silurian - Devonian boundary, and (b) the initial collision between Gondwana and Laurussia at c. 410-400 Ma, following the complete closure of the Rheic Ocean. This collision caused subduction of the most external margin of Gondwana and generated the HP-UHP metamorphic belt preserved in the allochthonous Upper Units exposed in the Variscan suture. The true Rheic Ocean suture is not represented in the mapped area of NW Iberia. in the Variscan suture (Fig. 4). The pull-apart basin currently being generated between the North American Plate and the Caribbean Plate can be considered a modern analog for the suggested tectonic setting, although in this case the lateral component is sinistral. The Gonâve microplate occupies the pull-apart basin and comprises oceanic litho- sphere with a rather thin or completely absent sedimentary cover (ten Brink et al., 2002). This oceanic lithosphere is being generated by the activity of the Mid-Cayman Spreading Centre (Fig. 5). In this modern analog, as was probably the case at the beginning of Pangea assembly, the pull-apart basin was generated following an initial collision that produced the high-P belts in northern Cuba and Hispaniola (Fig. 5) (GarcíaCasco et al., 2008; Sommer et al., 2011).

Continued dextral convergence finally caused the closure of the pull- apart basin and the accretion of buoyant oceanic lithosphere beneath the northern continent starting at c. 380 Ma (Careón and Purrido ophiolites; Dallmeyer et al., 1997). The accreted oceanic lithosphere is mostly metamorphosed to the amphibolite facies, but the occasional presence of corundum-bearing metamorphic soles indicates the local- ized presence of high thermal gradients (Díaz García et al., 1999). Later accretion of new Devonian mafic slices took place under greenschist facies conditions (Moeche Ophiolite), and was followed by the accretion of mafic complexes rimming the continental margin that formed within the Cambrian peri-Gondwanan volcanic arc (Vila de Cruces Ophiolite). The final outcome was the generation of a complex suture zone that records protracted dextral convergence and is charac- terized by the presence of a double ophiolitic belt of contrasting origin

c.395 Ma

Generation of an oceanic microplate.

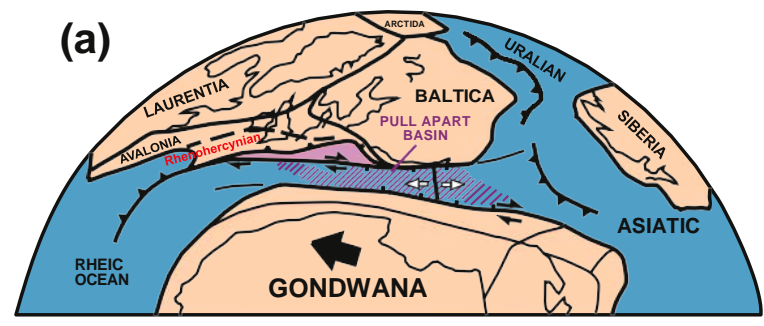

c.380-370 Ma

Second collision: Ophiolite obduction and second HP - event.

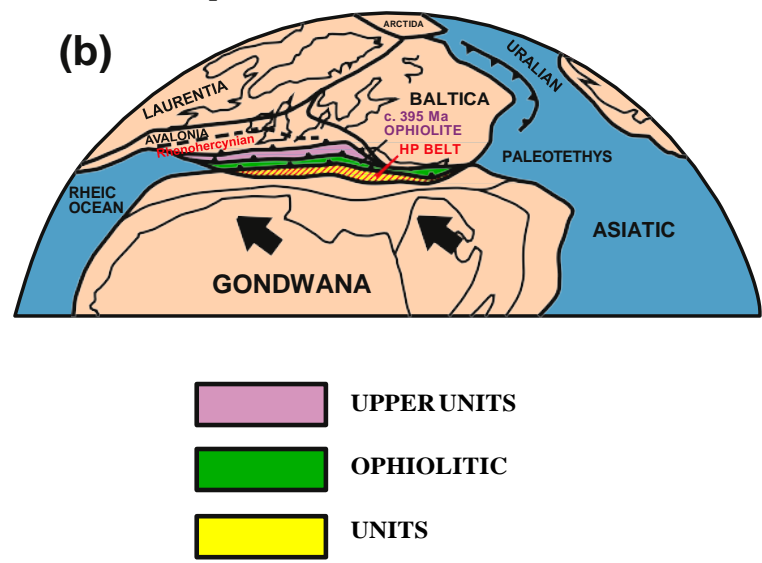

BASAL UNITS

Fig. 4. Reconstructions showing (a) dextral motion between Gondwana and Laurussia, which favored the opening of a rather ephemeral pull-apart basin at c. 395 Ma with generation of new oceanic lithosphere, and (b) the second and final collision at c. 380- $370 \mathrm{Ma}$, which caused the accretion of buoyant oceanic lithosphere followed by new sub- duction affecting the margin of Gondwana, thereby developing a second HP-LIT metamor- phic belt. The two different HP belts and the ophiolitic units dated at c. $395 \mathrm{Ma}$ can be identified in the allochthonous terranes that outline the Variscan suture from Iberia to the Bohemian Massif. 


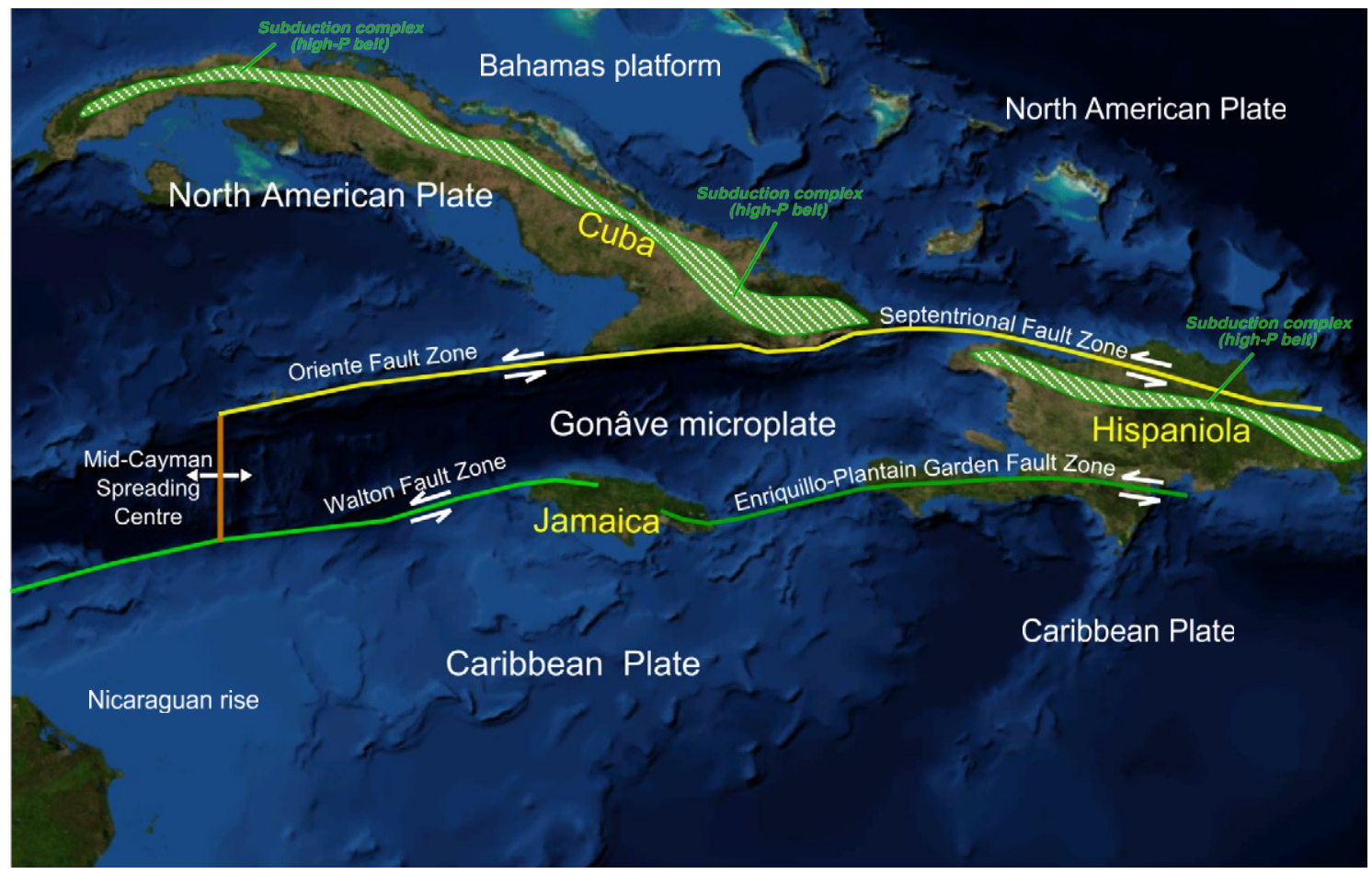

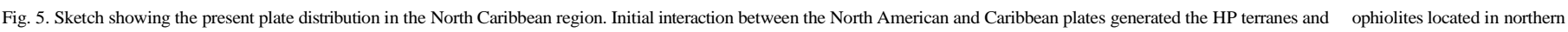

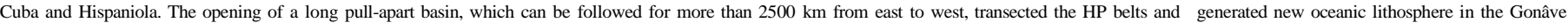

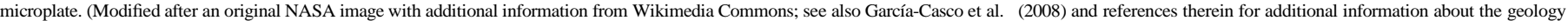
of the Caribbean region).

and ages: the Upper Ophiolitic Units of Devonian age and the Lower Ophiolitic Units of Cambrian age. The occurrence of a thick serpentinite mélange at the base of the allochthonous pile was interpreted in the context of dextral convergence (Somozas mélange, Fig. 2; Arenas et al., 2009).

The final collision between Gondwana and Laurussia started at c. $370 \mathrm{Ma}$ as a consequence of continued oblique dextral convergence (Díez Fernández et al., 2012b). It caused renewed north-directed subduction affecting a new section of the external Gondwanan margin with a more easterly provenance (in Gondwanan margin coordinates; Basal Units; Díez Fernández et al., 2010; Fuenlabrada et al., 2012). This is the suggested setting for the development of the second HP metamor- phic event, formed under LIT conditions and generating Ctype eclogites (Coleman et al., 1965), blueschists and HP metapelites (Fig. 4). Convergence continued for about 70 m.y. (Dallmeyer et al., 1997) as intracontinental deformation progressed southward, reaching inner sections of Gondwana while building a foreland fold and thrust belt in the external parts of the orogen.

\section{Conclusions}

Previous interpretations for the final assembly of Pangea call upon a singlestage collision between Gondwana and Laurussia in Carboniferous times. However, recent data regarding the origin and tectonothermal evolution of the allochthonous terranes involved in the Variscan suture suggest a more complex and longer history for the early stages in the assembly of the supercontinent. These data are consistent with two successive collisional events separated by the generation of a relatively ephemeral oceanic basin. The first collision occurred in Early Devonian times (before c. 400-390 Ma) and caused deep subduction of the most external margin of Gondwana and the generation of a HP-UHP metamorphic belt (Upper Units of the Variscan suture). Continued dextral motion between Gondwana and Laurussia favored the opening of a relatively large pull-apart basin at c. 400-395 Ma. The rapid closure of this basin started at c. $380 \mathrm{Ma}$ and caused the accretion of buoyant oceanic lithosphere of Devonian age below the northern continent. This oceanic lithosphere is represented by the most common ophiolites found in the European Variscan suture (Upper Ophiolitic Units). Mafic slices with a similar age and showing greenschist facies recrystallization were accreted later, followed by mafic complexes with Cambrian age generated by the activity of peri-Gondwanan volcanic arcs that progres- sively reached the collision zone as the basin shrank (Lower Ophiolitic Units). Finally, renewed dextral convergence led to a new collision with another section of the Gondwanan margin at c. $370 \mathrm{Ma}$ and the generation of a second HP-LIT belt (Basal Units). Convergence continued during the Carboniferous producing the complex intracontinental deformation that characterizes the Variscan belt.

\section{Acknowledgments}

Financial support for this research has been provided by the Spanish project CGL2012-34618 (Ministerio de Economía y Competitividad). Insightful reviews of the manuscript performed by Rob Strachan and an anonymous reviewer are gratefully acknowledged, as well as the excellent editing work of R. Damian Nance that significantly improved the final version of the manuscript. This paper is a contribution to Project 597 of the International Geological Correlation Programme: "Amalgamation and Breakup of Pangaea: the type example of the supercontinent".

\section{References}

Ábalos, B., Puelles, P., Gil Ibarguchi, J.I., 2003. Structural assemblage of high-pressure mantle and crustal rocks in a subduction channel (Cabo Ortegal, NW Spain). Tectonics 22, 1006. http://dx.doi.org/10.1029/2002tc001405.

Abati, J., Dunning, G.R., Arenas, R., Díaz García, F., González Cuadra, P., Martínez Catalán, J.R., Andonaegui, P., 1999. Early Ordovician orogenic event in Galicia (NW Spain): evidence from $\mathrm{U}-\mathrm{Pb}$ ages in the uppermost unit of the Ordenes Complex. Earth and Planetary Science Letters 165, 213-228.

Abati, J., Castiñeiras, P., Arenas, R., Fernández-Suárez, J., Gómez Barreiro, J., Wooden, J., 2007. Using SHRIMP-RG U-Pb zircon dating to unravel tectonomagmatic events in 
arc environments. The early Paleozoic arc of NW Iberia revisited. Terra Nova 19, 432-439.

Abati, J., Gerdes, A., Fernández-Suárez, J., Arenas, R., Whitehouse, M.J., Díez Fernández, R., 2010. Magmatism and early-Variscan continental subduction in the northern Gond- wana margin recorded in zircons from the basal units of Galicia, NW Spain. Geological Society of America Bulletin 122, 219-235

Andonaegui, P., Castiñeiras, P., González Cuadra, P., Arenas, R., Sánchez Martínez, S., Abati, J., Díaz García, F., Martínez Catalán, J.R., 2012. The Corredoiras orthogneiss (NW Iberian Massif): geochemistry and geochronology of the Paleozoic magmatic suite developed in a peri-Gondwanan arc. Lithos 128-131, 84-99.

Arenas, R., Gil Ibarguchi, J.I., González Lodeiro, F., Klein, E., Martínez Catalán, J.R., Ortega Gironés, E., de Pablo Maciá, J.G., Peinado, M., 1986. Tectonostratigraphic units in the complexes with mafic and related rocks of the NW of the Iberian Massif. Hercynica 2, 87-110.

Arenas, R., Rubio Pascual, F.J., Díaz García, F., Martínez Catalán, J.R., 1995. High- pressure microinclusions and development of an inverted metamorphic gradient in the Santiago Schists (Órdenes Complex, NW Iberian Massif, Spain): evidence of subduction and syncollisional decompression. Journal of Metamorphic Geology 13, 141-164.

Arenas, R., Abati, J., Martínez Catalán, J.R., Díaz García, F., Rubio Pascual, F.J., 1997. P-T evolution of eclogites from the Agualada Unit (Órdenes Complex, NW Iberian Massif, Spain): implications for crustal subduction. Lithos 40, 221-242.

Arenas, R., Martínez Catalán, J.R., Sánchez Martínez, S., Fernández-Suárez, J., Andonaegui, P., Pearce, J.A., Corfu, F., 2007a. The Vila de Cruces Ophiolite: a remnant of the early Rheic Ocean in the Variscan suture of Galicia (NW Iberian Massif). Journal of Geology 115, 129-148.

Arenas, R., Martínez Catalán, J.R., Sánchez Martínez, S., Díaz García, F., Abati, J., Fernández- Suárez, J., Andonaegui, P., Gómez-Barreiro, J., 2007b. Paleozoic ophiolites in the Variscan suture of Galicia (northwest Spain): distribution, characteristics and meaning. In: Hatcher Jr., R.D., Carlson, M.P. McBride, J.H., Martínez Catalán, J.R. (Eds.), 4-D Framework of Continental Crust. Geological Society of America Memoir, 200, pp. 425-444.

Arenas, R., Sánchez Martínez, S., Castiñeiras, P., Jeffries, T.E., Díez Fernández, R., Andonaegui, P., 2009. The basal tectonic mélange of the Cabo Ortegal Complex (NW Iberian Massif): a key unit in the suture of Pangea. Journal of Iberian Geology 35, 85-125.

Arenas, R., Sánchez Martínez, S., Gerdes, A., Albert, R., Díez Fernández, R., Andonaegui, P., 2013. Reinterpreting the Devonian ophiolites involved in the Variscan suture: U-Pb and Lu-Hf zircon data of the Moeche Ophiolite (Cabo Ortegal Complex, NW Iberia). International Journal of Earth Sciences. http://dx.doi.org/10.1007/s00531-013-0880-x (in press).

Ballèvre, M., Bosse, V., Ducassou, C., Pitra, P., 2009. Palaeozoic history of the Armorican Massif: models for the tectonic evolution of the suture zones. Comptes Rendus Geoscience 341, 174-201.

Ballèvre, M., Bosse, V., Ducassou, C., Paquette, J.L., Peucat, J.J., Pitra, P., Poujol, M., Ruffet, G., 2012. Geometry and correlation of the nappe stack in the Ibero-Armorican arc across the Bay of Biscay: a joint French-Spanish project. Part 1: the data. Géologie de la France 1, 60-61.

Beaumont, C., Jamieson, R.A., Butler, J.P., Warren, C.J., 2009. Crustal structure: a key constraint on the mechanism of ultra-high-pressure rock exhumation. Earth and Planetary Science Letters 287, 116-129.

Clark, A.H., Scott, D.J., Sandeman, H.A., Bromley, A.V., Farrar, E., 1998. Siegenian generation of the Lizard ophiolite: U-Pb zircon age data for plagiogranite, Porthkerries, Cornwall. Journal of the Geological Society of London 155, 595-598.

Coleman, R.G., Lee, D.E., Beatty, L.B., Brannock, W.W., 1965. Eclogites and eclogites — their differences and similarities. Geological Society of America Bulletin 76, 483-508.

Dallmeyer, R.D., Martínez Catalán, J.R., Arenas, R., Gil Ibarguchi, J.I., Gutiérrez Alonso, G., Farias, P., Aller, J., Bastida, F., 1997. Diachronous Variscan tectonothermal activity in the NW Iberian Massif: evidence from ${ }^{40} \mathrm{Ar} /{ }^{39} \mathrm{Ar}$ dating of regional fabrics. Tectonophysics 277, 307-337.

Díaz García, F., Arenas, R., Martínez Catalán, J.R., González del Tánago, J., Dunning, G.R., 1999. Tectonic evolution of the Careón Ophiolite (northwest Spain): a remnant of oceanic lithosphere in the Variscan Belt. Journal of Geology 107, 587-605.

Díaz García, F., Sánchez Martínez, S., Castiñeiras, P., Fuenlabrada, J.M., Arenas, R., 2010. A periGondwanan arc in NW Iberia. II: assessment of the intra-arc tectonothermal evo- lution through U-Pb SHRIMP dating of mafic dykes. Gondwana Research 17, 352-362. Díez Fernández, R., Martínez Catalán, J.R., Gerdes, A., Abati, J., Arenas, R., Fernández- Suárez, J., 2010. U-Pb ages of detrital zircons from the basal allochthonous units of NW Iberia: provenance and paleoposition on the northern margin of Gondwana during the Neoproterozoic and Paleozoic. Gondwana Research 18, 385-399.

Díez Fernández, R., Castiñeiras, P., Gómez Barreiro, J., 2012a. Age constraints on Lower Pa- leozoic convection system: magmatic events in the NW Iberian Gondwana margin. Gondwana Research 21, 1066-1079.

Díez Fernández, R., Martínez Catalán, J.R., Arenas, R., Abati, J., 2012b. The onset of the assembly of Pangaea in NW Iberia: constraints on the kinematics of continental subduction. Gondwana Research 22, 20-25.

Díez Fernández, R., Foster, D.A., Gómez Barreiro, J., Alonso-García, M., 2013. Rheological control on the tectonic evolution of a continental suture zone: the Variscan example from NW Iberia (Spain). International Journal of Earth Sciences. http://dx.doi.org/ 10.1007/s00531-013-0885-5.

Dubińska, E., Bylina, P., Kozlowski, A., Dörr, W., Nejbert, K., 2004. U-Pb dating of serpentinization: hydrothermal zircon from a metasomatic rodingite shell (Sudetic ophiolite, SW Poland). Chemical Geology 203, 183-203.

Faryad, S.W., Kachlík, V., 2013. New evidence of blueschist facies rocks and their geoectonic implication for Variscan suture (s) in the Bohemian Massif. Journal of Metamorphic Geology 31, 63-82.
Fernández-Suárez, J., Díaz García, F., Jeffries, T.E., Arenas, R., Abati, J., 2003. Con- straints on the provenance of the uppermost allochthonous terrane of the NW Iberian Massif: inferences from detrital zircon U-Pb ages. Terra Nova 15, 138-144.

Fernández-Suárez, J., Arenas, R., Abati, J., Martínez Catalán, J.R., Whitehouse, M.J., Jeffries, T.E., 2007. U-Pb chronometry of polymetamorphic high-pressure granu- lites: an example from the allochthonous terranes of the NW Iberian Variscan belt. In: Hatcher Jr., R.D., Carlson, M.P., McBride, J.H., Martínez Catalán, J.R. (Eds.), 4-D Framework of Continental Crust. Geological Society of America Memoir, 200, pp. 469-488.

Fuenlabrada, J.M., Arenas, R., Sánchez Martínez, S., Díaz García, F., Castiñeiras, P., 2010. A periGondwana arc in NW Iberia. I: isotopic and geochemical constraints on the origin of the arc — a sedimentary approach. Gondwana Research 17, 338-351.

Fuenlabrada, J.M., Arenas, R., Díez Fernández, R., Sánchez Martínez, S., Abati, J., López Carmona, A 2012. Sm-Nd isotope geochemistry and tectonic setting of the metasedimentary rocks from the basal allochthonous units of NW Iberia (Variscan suture, Galicia). Lithos 148, 196-208.

García-Casco, A., Iturralde-Vinent, M.A., Pindell, J., 2008. Latest Cretaceous collision/accretion between the Caribbean plate and Caribeana: origin of metamorphic terranes in the Greater Antilles. International Geology Review 50, 781-809.

Gómez Barreiro, J., Martínez Catalán, J.R., Arenas, R., Castiñeiras, P., Abati, J., Díaz García, F., Wijbrans, J.R. 2007. Tectonic evolution of the upper allochthon of the Órdenes complex (northwestern Iberian Massif): Structural constraints to a polyorogenic peri-Gondwanan terrane. In: Linneman, U. Nance, R.D., Kraft, P., Zulauf, G. (Eds.), The Evolution of the Rheic Ocean: From AvalonianCadomian Active Margin to Alleghenian-Variscan Collision. Geological Society of America Special Paper, 423, pp. 315-332.

Kroner, U., Romer, R.L., 2013. Two plates - many subduction zones: the Variscan orogeny reconsidered. Gondwana Research 24, 298-329.

Kryza, R., Pin, C., 2010. The Central-Sudetic ophiolites (SW Poland): petrogenetic issues, geochronology and palaeotectonic implications. Gondwana Research 17, 292-305.

Lardeaux, J.M., Ledru, P., Daniel, I., Duchene, S., 2001. The VariscanFrench MassifCentral — a new addition to the ultra-high pressure metamorphic 'club': exhumation processes and geodynamic consequences. Tectonophysics 332, 143-167.

López Carmona, A., Pitra, P., Abati, J., 2013. Blueschist-facies metapelites from the Malpica-Tui Unit (NW Iberian Massif): phase equilibria modelling and $\mathrm{H}_{2} \mathrm{O}$ and $\mathrm{Fe}_{2} \mathrm{O}_{3}$ influence in high-pressure assemblages. Journal of Metamorphic Geology 31, 263-280.

Martínez Catalán, J.R., 2011. Are the oroclines of the Variscan belt related to late Variscan strike-slip tectonics? Terra Nova 23, 241-247.

Martínez Catalán, J.R., Arenas, R., Abati, J., Sánchez Martínez, S., Díaz García, F., Fernández- Suárez, J., González Cuadra, P., Castiñeiras, P., Gómez Barreiro, J., Díez Montes, A., González Clavijo, E. Rubio Pascual, F.J., Andonaegui, P., Jeffries, T.E., Alcock, J.E., Díez Fernández, R., López Carmona, A., 2009. A rootless suture and the loss of the roots of a mountain chain: the Variscan belt of NW Iberia. Comptes Rendus Geoscience 341, 114-126.

Matte, P., 2001. The Variscan collage and orogeny (480-290 Ma) and the tectonic definition of the Armorica microplate: a review. Terra Nova 13, 122-128.

Murphy, J.B., Nance, R.D., 2008. The Pangea conundrum. Geology 36, 703-706,

Murphy, J.B., Cousens, B.L., Braid, J.A., Strachan, R.A., Dostal, J., Keppie, J.D., Nance, R.D., 2011 Highly depleted oceanic lithosphere in the Rheic Ocean: implications for Paleozoic plate reconstructions. Lithos 123, 165-175.

Nance, R.D., Gutiérrez-Alonso, G., Keppi, J.D., Linnemann, U., Murphy, J.B., Quesada, C., Strachan, R.A., Woodcock, N.H., 2010. Evolution of the Rheic Ocean. Gondwana Research 17, 194-222.

Nutman, A.P., Green, D.H., Cook, C.A., Styles, M.T., Holdsworth, R.E., 2001. SHRIMP U-Pb zircon dating of the exhumation of the Lizard Peridotite and its emplacement over crustal rocks: constraints for tectonic models. Journal of the Geological Society of London 158, 809-820.

Ordóñez Casado, B., Gebauer, D., Schäfer, H.J., Gil Ibarguchi, J.I., Peucat, J.J., 2001. A single Devonian subduction event for the HP/HT metamorphism of the Cabo Ortegal complex within the Iberian Massif. Tectonophysics 332, 359-385.

Pin, C., Paquette, J.L., Santos Zalduegui, J.F., Gil Ibarguchi, J.I., 2002. Early Devonian supra- subduction zone ophiolite related to incipient collisional processes in the Western Variscan Belt: the Sierra de Careón unit, Órdenes Complex, Galicia. In: Martínez Catalán, J.R., Hatcher Jr., R.D., Arenas, R., Díaz García, F. (Eds.), Variscan-Appalachian Dynamics: The Building of the Late Paleozoic Basement. Geological Society of America Special Paper, 364, pp. 57-71.

Pin, C., Paquette, J.L., Ábalos, B., Santos, J.F., Gil Ibarguchi, J.I., 2006. Composite origin of an early Variscan transported suture: Ophiolitic units of the Morais Nappe Complex (north Portugal). Tectonics 25, 1-19.

Platt, J.P., 1986. Dynamic of orogenic wedges and the uplift of high-pressure metamorphic rocks. Geological Society of America Bulletin 97, 1037-1053.

Rodríguez, J., Cosca, M.A., Gil Ibarguchi, J.I., Dallmeyer, R.D., 2003. Strain partitioning and preservation of ${ }^{40} \mathrm{Ar}{ }^{39} \mathrm{Ar}$ ages during Variscan exhumation of a subducted crust (Malpica-Tui Complex, NW Spain). Lithos 70, 111-139.

Sánchez Martínez, S., Arenas, R., Díaz García, F., Martínez Catalán, J.R., Gómez Barreiro, J., Pearce, J., 2007. The Careón Ophiolite, NW Spain: supra-subduction zone setting for the youngest Rheic Ocean floor. Geology 35, 53-56.

Sánchez Martínez, S., Arenas, R., Gerdes, A., Castiñeiras, P., Potrel, A., Fernández-Suárez, J., 2011. Isotope geochemistry and revised geochronology of the Purrido Ophiolite (Cabo Ortegal Complex, NW Iberian Massif): Devonian magmatism with mixed sources and involved Mesoproterozoic basement. Journal of the Geological Society of London 168, 733-750. 
Sánchez Martínez, S., Gerdes, A., Arenas, R., Abati, J., 2012. The Bazar Ophiolite of NW Iberia: a relict of the Iapetus-Tornquist Ocean in the Variscan suture. Terra Nova 24, 283-294. Sommer, M., Hüneke, H.,

Meschede, M., Cobiella-Reguera, J., 2011. Geodynamic model of the northwestern Caribbean: scaled reconstruction of Late Cretaceous to Late Eocene plate boundary relocation in Cuba. Neues Jahrbuch

Monatschefte 259, 299-312.

für Geologie und Paläontologie,

Stampfli, G.M., Borel, G.D., 2002. A plate tectonic model for the Paleozoic and Mesozoic constrained by dynamic plate boundaries and restored synthetic oceanic isochrons. Earth and Planetary Science Letters 196, 17-33. ten Brink, U.S., Coleman, D.F., Dillon, W.P., 2002. The nature of the crust under Cayman Trough from gravity. Marine and Petroleum Geology 19, 971-987.

Warren, C.J., Beaumont, C Jamieson, R.A., 2008. Modelling tectonic styles and ultra-high pressure (UHP) rock exhumation during the transition from oceanic subduction to continental collision. Earth and Planetary Science Letters 267, 129-145.

Weil, A.B., Gutiérrez-Alonso, G., Johnston, S.T., Pastor-Galán, D., 2012. Kinematic constraints on buckling a lithospheric-scale orocline along the northern margin of Gondwana: a geologic synthesis. Tectonophysics 582, 25-49. 